\title{
Vísindagreinar á ensku í netútgáfu Læknablaðsins
}

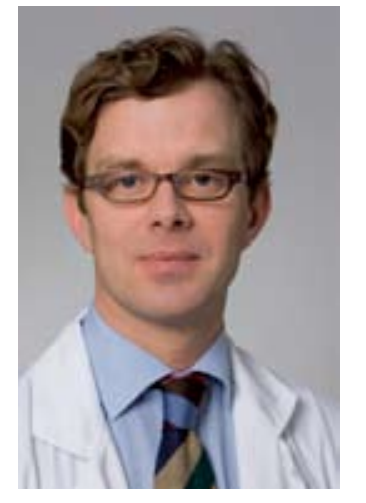

Tómas Guðbjartsson

tomasgud@landspitali.is

Höfundur er hjarta- og lungnaskurðlæknir á Landspítala og prófessor við læknadeild HÍ, hann situr líka i ritstjórn Læknablaðsins.

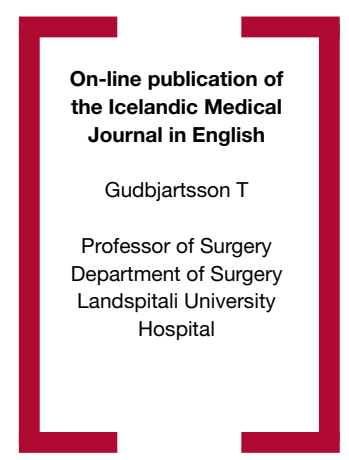

Á síðustu árum hafa verið gerðar ýmsar breytingar á Læknablaðinu með pað að markmiði að gera pað aðgengilegra og læsilegra fyrir lesendur. Auk pess hefur netútgáfan verið efld, en notkun hennar fer vaxandi. Blaðið er nú skráð í alla helstu gagnagrunna heilbrigðis- og lífvísinda, par á meðal gagnagrunna Medline, Web of Science (ISI) og Scopus. ${ }^{1}$ Kjölfesta í útgáfu blaðsins eru ritrýndar vísindagreinar, tvær til fjórar greinar í hverju tölublaði. Í nýlegri úttekt kom fram að fjöldi ritrýndra vísindagreina í Læknablađinu hefur haldist tiltölulega óbreyttur síðustu fimm ár. Á sama tíma hefur sést mikil aukning í birtingu fræðigreina íslenskra vísindamanna í erlendum vísindaritum. Pví er ljóst að vaxtarbroddur î vísindastarfi hér á landi hefur ekki skilað sér sem skyldi á síður blaðsins. ${ }^{2}$ Einnig er umhugsunarefni að sumar sérgreinar birta sjaldan eða aldrei vísindagreinar í blaðinu, jafnvel pótt rannsóknavirkni sé mikil og birtingar í erlendum vísindaritum tíðar. Höfundar leitast 1 staðinn við að birta rannsóknir sínar í erlendum vísindaritum, sem oftar er vitnað til og hafa stærri lesendahóp. Petta er skiljanlegt, ekki síst í ljósi pess hve lítið málsvæði íslenskunnar er. Á pessari próun er pó önnur hlið. Oft er um að ræða rannsóknir á íslenskum sjúklingum, jafnvel gerðar við séríslenskar aðstæður. Einn helsti markhópur slíkra rannsókna eru íslenskir læknar og heilbrigðisstarfsfólk. Pví er mikilvægt að niðurstöður pessara rannsókna komi peim fyrir sjónir. Læknablađið er slíkur vettvangur. Blaðið er gefið út í 1700 eintökum og berst öllum læknum á Íslandi. Pví er auðvelt að ná til lækna úr mismunandi sérgreinum. Auk pess hentar blaðið ágætlega fyrir kennsluefni, enda fá flestir læknanemar blaðið sent heim til sín. Loks er netútgáfa blaðsins öllum opin og auðvelt að nálgast efni sem áður hefur birst í blaðinu.

Í ritstjórn Læknablaðsins hafa verið ræddar leiðir til að koma betur til móts við íslenska höfunda og um leið auka lestur blaðsins og streymi á innsendum greinum. Í allmörg ár hefur verið boðið upp á tvíbirtingu greina. Erlendar greinar eru pá birtar á íslensku í Læknablaðinu með pví skilyrði að erlenda blaðið hafi gefið til pess leyfi sitt. Fáir hafa pó nýtt sér pennan valkost, enda erlend tímarit sum ekki jákvæð fyrir tvíbirtingu niðurstaðna. Nýlega ákvað ritstjórn að bjóða höfundum upp á að birta greinar á ensku í netútgáfu blaðsins. Skilyrði fyrir slíkri birtingu er að greinin birtist jafnhliða á íslensku í prentútgáfu blaðsins. Pví er í engu hvikað frá peirri yfirlýstu stefnu blaðsins að hafa prentútgáfuna á vandaðri íslensku. Fyrsta greinin með pessu sniði birtist í október síðastliðnum ${ }^{3}$ og fleiri greinar með enskri pýðingu eru væntanlegar. Í völdum tilvikum getur ritstjórn ákveðið að borga slíka pýðingu, en annars fellur kostnaður við pýðingu á höfunda kjósi peir að fá greinina birta á ensku. Um leið ætti áhugi erlendra vísindamanna að senda inn greinar í blaðið að aukast.

Sumum gæti virst að hér sé um stórt skref að ræða og vegið að íslensku útgáfunni. Sú er pó ekki raunin. Ensk útgáfa vísindagreina í prentútgáfu Læknablaðsins hefur áður verið til umræðu ${ }^{4}$ og vakti töluverð viðbrögð. ${ }^{5}$ Önnur íslensk vísindarit hafa valið pá leið, til dæmis hið virta vísindarit Jöklarannsóknarfélags Íslands, Jökull, sem hefur verið gefið út frá árinu 1951. Í dag held ég að flestir séu peirrar skoðunar að Læknablaðið eigi að vera á góðri íslensku og standa beri vörð um notkun íðorða. Vönduð íslensk útgáfa parf pó ekki að standa í vegi fyrir netútgáfu á ensku. Vísir að enskri útgáfu í Læknablaðinu hefur verið til staðar í fjölmörg ár. Frá árinu 1950 hefur birst enskt ágrip með íslensku prentútgáfunni og frá árinu 2007 hafa myndir og töflur á ensku birst í netútgáfunni. Petta reyndust mikilvæg skref í pví ferli að Læknablaððð fékkst skráð á Medline árið 2005 og í lok pessa árs í gagnagrunna Web of Science (ISI) og Scopus. Að mínu mati er pví eðlilegt að stíga frekara skref og birta greinar í heild sinni á ensku á netinu. Um leið er mikilvægt að tryggja að enska netútgáfan sé aðgengileg í erlendu gagnagrunnunum og er slík vinna í gangi.

\section{Heimildir}

1. Björnsson J. Drög að áfangaskýrslu. Læknablaðið 2008; 94: 443

2. Guðbjartsson T, Sigurðsson E. Hverjir skrifa í Læknablaðið? - Yfirlit yfir fræðigreinar síðustu fimm ára. Læknablaðið 2009: 95: 683-6.

3. Gunnarsson SI, Torfason B, Sigfússon G, Helgason H, Guðbjartsson T. Árangur skurðaðgerða við meðfæddri ósæðarprengingu hjá börnum á Íslandi 1990-2006. Læknablaðið 2009; 95: 647-53.

4. Guðbjartsson T. Vangaveltur um framtíð Læknablaðsins sem vísindarits. Læknablaðið 2002; 88: 471

5. Sveinsson S. Um skurðlækna og gengi Læknablaðsins. Læknablaðið 2002; 88: 578-9. 